\title{
Institutional Barriers of Low Carbon Development Planning in Indonesian Small Cities
}

\author{
Hendricus Andy Simarmata1,2, Adriadi Dimastanto², Soly Iman Santoso'2, Dharma Kalsuma1 \\ ${ }^{1}$ Universitas Indonesia, Jakarta, Indonesia \\ ${ }^{2}$ Indonesian Association of Urban and Regional Planners (IAP), Jakarta, Indonesia \\ Email: hendricus.andy@ui.ac.id, andybanjar@yahoo.com
}

Received 24 June 2014; revised 20 July 2014; accepted 15 August 2014

Copyright (C) 2014 by authors and Scientific Research Publishing Inc.

This work is licensed under the Creative Commons Attribution International License (CC BY).

http://creativecommons.org/licenses/by/4.0/

(c) (i) Open Access

\begin{abstract}
Recently, building low carbon development pathway becomes a mandatory task for many big cities through spatial planning. For a small city that still has many green areas, it assumed that the mainstreaming process of low carbon development into spatial planning is easier. However, studies that explore planning challenges of small cities in building a pathway of low carbon development is still limited. This study aims to examine the mainstreaming process of low carbon development strategies into the spatial planning through three case studies of Indonesian small cities. The quantitative and qualitative data collected from the fieldwork in three small cities: Kasongan, from June to December 2010; Merauke, from June to December 2011; and Sendawar, from January to June 2013. We argue that the small cities, which assumed have main potential carbon storage, in fact, have also the extensive carbon emission. They have the institutional barriers, including the limited knowledge on the economic opportunities of low carbon development, the lack of technical capacity of local government in implementing low carbon planning process, and the inadequate data to support the planning method. The leadership of Mayor is crucial in opening the barriers, but not to create the pathway yet. Therefore, we suggest that providing technical support of low carbon development, strengthening institutional capacity, and empowering the local community would optimize the mainstreaming process.
\end{abstract}

\section{Keywords}

Low Carbon, Urban, Planning, Indonesia

\section{Introduction}

Low carbon development agenda has become a mandatory task for many large cities both in developed and de-

How to cite this paper: Simarmata, H.A., Dimastanto, A., Santoso, S.I. and Kalsuma, D. (2014) Institutional Barriers of Low Carbon Development Planning in Indonesian Small Cities. Low Carbon Economy, 5, 105-116.

http://dx.doi.org/10.4236/lce.2014.53011 
veloping countries since 70\% of carbon emissions come from urban activities [1]. A range of urban sectors, such as "transportation, energy generation and industrial production" [2], that contribute to greenhouse gasses (GHG) emission need to be managed properly in order to achieve the lowest emission for the future. Managing those activities should not only be a national agenda, but also city government itself. Therefore, the agenda need to be synchronized into sustainable development policy [3] and the plan should resolve the priorities of climate change mitigation and development agenda of the country [4].

Those thus would need a planning institutional transformation. The Project Catalyst Brief (2009) as cited in Hedger et al. (2011) has recommended some key factors to make successful planning. The factors are:

1) Senior leadership from within the government; 2) a strong basis in scientific and economic data that yields a robust, credible assessment of mitigation potential and the costs of alternatives; 3) stakeholder engagement to facilitate data collection and support across critical sectors; 4) ongoing iteration that builds consensus around priorities and incorporates the latest advances in scientific knowledge, international agreements, and technological developments; 5) accelerated learning and the widespread adoption of best practices could be achieved by building on experience to date, facilitating peer to peer learning among countries; 6) providing access to technical support; and 7) developing general guidelines [5].

Recently, the discourse of low carbon development at city level mostly discusses the interrelation between urban system and global warming. It was believed that urban economic activities produce more than half of $\mathrm{CO}_{2}$ emission. In the other hand, those urban activities have shaped the spatial structure, infrastructure networks, and land use pattern. It thus would lead the discussion to the role of spatial planning. It certainly would shift the spatial planning process, from the dispersed to compact structure; from high to low dependent on fuel energy; and from low to a high proportion of green open spaces. Therefore, for many cities in developing countries, the issues now are about how to realize the compact urban structure that supported by mass public transportation system; how to use energy efficiently or use the unused or renewable energies; and how to promote urban greening [6].

Those issues above have already generated many global initiatives, including the urban low emission development strategy (LEDS). The LEDS program covers "intersection of development and greenhouse gas mitigation [and can be] the economic development plans or strategies that encompass low-emission and/or climate-resilient economic growth" [7]. One of the LEDS program is Urban LEDS that was funded by European Commission (EC) and implemented by International Council for Local Environmental for sustainability (ICLEI) and United Nations Habitat [8]. This program has been implemented since 2012 in selected local governments in Brazil, India, Indonesia and South Africa, especially for the metropolitan and large cities.

However, the low carbon agenda is not limited to the large cities only. Small cities, which based on a low population factor, small economic activities, and the availability of open space, have also great potential in applying the low carbon development agenda. The dominance of green lands, which is mostly surrounding its urban center, is certainly a great asset to be capitalized in order to achieve a low carbon development. It would differentiate the development strategy to the large cities. The role of spatial planning that balance the interrelation between low-emission development, economic growth, and social welfare can be more significant to create the development pathway. It is a challenge for the spatial planning in small cities to manage the relationship since they need to increase economic growth, but, on the other hand, they are also mandated to maintain environment balance by limiting development that triggers the emission.

Indonesia as a tropical archipelagic country, which has 497 administrative districts and cities, has only 10 metropolitan cities (more than 1 million residents), 13 large cities, and 56 medium cities [9]. The rest of them or 80 percent are small cities (less than 100 thousand inhabitants). It means the application of low carbon development in an urban area will have also a significant impact if focused on the small cities. Nevertheless, there are still limited studies that examine the potentiality or challenges for the small cities to contribute on the low carbon development. Whereas they have potential assets of carbon storage that probably significantly contribute to the low carbon development.

Indonesia has taken a strategic vision to implement a low carbon development agenda. The Presidential Regulation Nr. 61/2011 regarding the National Action Plan (NAP) of reducing GHG has mentioned that Indonesia commit to reducing GHG emissions to $26 \%$ by their own efforts or business as usual, and to $41 \%$ by international assistance by 2020 [10]. The main respective sectors are forestry and peat land, energy, industrial and transportation, and waste management. Even though, the national regulation did not explicitly entreat the cities to contribute, the national government has invited the local government to participate through the Green City Development Program (P2KH) since 2012. Besides ordering the cities to allocate adequate land for green open space for 
about $30 \%$ of the total area of the city [11], the P2KH also encourage cities to implement 8 principles of green city, such as environmental-friendly urban planning and design, efficient energy consumption, effective water management, waste management cycle, green building, sustainable transportation, and people support (green communities) [12]. The P2KH, which initiated by Directorate General of Spatial Planning of Ministry of Public Works, has already been followed by 112 large and medium cities [13], but not by the small cities yet. Therefore, the part of Indonesian small cities in contributing to low carbon development at national level is questioned.

In this study, the authors intend to know how the spatial planning process of small cities considered and was influenced by the low carbon development. What the barriers are for the small cities to make a low carbon development plan is the central question of this study. In order to have comprehensive result, the authors selected the small cities that still have potential carbon storage (represented by the availability of forestlands), but located in the different geographical location (represented by watershed). First, Merauke that lies on the coastal area (downstream). Second, Kasongan that located on the riverside (in the middle). Third, Sendawar that located in the upstream area. Through three case studies of the small cities in Indonesia, this paper examines the challenges faced by local governments in creating low-carbon development pathway through the spatial planning process. Specifically, this paper aims to examine the mainstreaming process of low carbon development strategies into the spatial planning.

\section{Methodology}

This study use quantitative and qualitative research. The quantitative research conducted to examine the potentiality of low carbon development through potential carbon storage measurement. We used the primary calculation unit of a $\mathrm{CH}_{4}$ to $\mathrm{CO}_{2}$ emissions produced per unit of ton per hectare in one year per land use type that was created by Jauhianen et al. in 2007 [14]. They estimated the level of $\mathrm{CO}_{2}$ and $\mathrm{CH}_{4}$ emissions from various forms of land use. They argued that the carbon stored in the soil and plants can 10 times higher the carbon stored by the land and the plants on a regular mineral soil, especially in the tropical region.

We used satellite imagery data of land sat TM-7 in 2012 to generate the existing land cover pattern. We conducted ground truth survey to verify the land cover types and investigated the soils. We applied the ER Mapper 7.0 for satellite image interpretation and ArcGIS 10.0 to proceed and analyze the spatial data, especially for the calculating query. The qualitative research conducted to identify and analyze the mainstreaming process through indepth interview, participant observation, and focus group discussion (FGD). The interviewees are planning consultants, local government officers, society, and NGO's (FGD forum involved 18 participants). The participant observation and FGD played within the spatial planning process in which the role of authors as a planning consultant for the government agency. Those qualitative research instruments used to understand the green perspectives among stakeholders, the vision of low carbon development, and knowledge gap that came up within the planning process.

Since we aim to investigate the spatial planning process, we conducted field researches in the time of the spatial planning project are conducted in each city. The fieldwork in the City of Kasongan lasted during the spatial planning project from June to December 2010. The fieldwork in the City of Merauke lasted during spatial planning project from June to December 2011, and the fieldwork in the City of Sendawar lasted from January to June 2013 during the spatial planning project of Kutai Barat district. We use three case studies in order to know the variety of the carbon potential in the small cities and different stories of the mainstreaming process that has been taken by them. Both would provide a comprehensive picture about the low carbon development agenda in the small cities.

\section{Case Studies Area}

Merauke is the capital city of Merauke district, located in Papua Island, the eastern part of Indonesia, particularly in the south border area between Indonesia and Papua New Guinea (PNG). The urban area is about 7000 hectares, which inhabited by around 80 thousand inhabitants [15]. Merauke, which developed alongside the Maro River, has still non-built area for its major land use. The urban economy is mostly structured by the trade and services either formal or informal sectors. It served most of the southern part of Papua Island, including several villages in PNG. The city has insufficient power supply, only served by 19 diesel engines with $80 \mathrm{~kW}-1000 \mathrm{~kW}$ electric power. Therefore, the power outage often occurs both in the day and night (Field Note, 12 November 2011). There is also no mass transport system yet, they still dependent on private motorcycles and cars. They use diesel power 
for industry, as well. In short, they still depend on fossil fuel energy.

Kasongan, a small town in Central Kalimantan province $( \pm 950 \mathrm{~km}$ from Jakarta), is the capital city of Katingan District. Kasongan is an urbanizing area that separated by 200 meters wide Katingan River, which then makes the spatial development based on a river-oriented city. The total area of Kasongan is about 3315 hectares, however, 90 percent has still not been built yet. The governmental sectors dominate the urban economic activities and become the main trigger for migration. Kasongan has only 12 thousand inhabitants in 2009 [16]. Similar with Merauke, Kasongan is still lacking power supply and still depend on the fossil-fuel transportation, as well.

Sendawar is the capital of Kutai Barat District in East Kalimantan province ( $\pm 1.650 \mathrm{~km}$ from Jakarta). Sendawar consists of some sub-district and village with a spacious of approximately 20.591 ha. However, only $7 \%$ of its area is a built-up area. As just born in early 2000, the city of Sendawar is still in the beginning time to be urbanized. Most of Sendawar area consists of Melak, Sekolaq Darat, and Barong Tongkok [17]. The population of Sendawar is approximately 36 thousand residents ${ }^{1}$ [18]. Sendawar also lacks energy, even though the district has coal sources and mining activities. Orientation of the location of the three study areas (Merauke, Kasongan, and Sendawar), can be seen in Figure 1.

\section{Potential Carbon Balance: High Storage, but High Emission}

An analysis of the carbon storage capacity used the land use interpretation. "Soils represent a short to long-term carbon storage medium and contain more carbon than all terrestrial vegetation and the atmosphere combined” [19]. By planning proper land use model, the cities can increase the carbon sinkers that accumulate and store some carbon-containing chemical compound for an open-ended period, and can enlarge the high carbon sequestration that removing carbon from the atmosphere and depositing it in a reservoir [19]. The small cities have more potential natural reservoirs that would be a potential asset to increase the carbon sink and/or carbon sequestration.

The land use composition of three cities is dominated by non-built up area, mostly forest and swamp area, as shown in Figure 2. The urban area that represented by built up area is very small and most commercial area inhabited by small-scale projects. The representation of urban life in those three locations is characterized by low human mobility and high usage of the motorcycle (Authors field note, 2010, 2011, and 2013). Most of the settlement are self-made by the

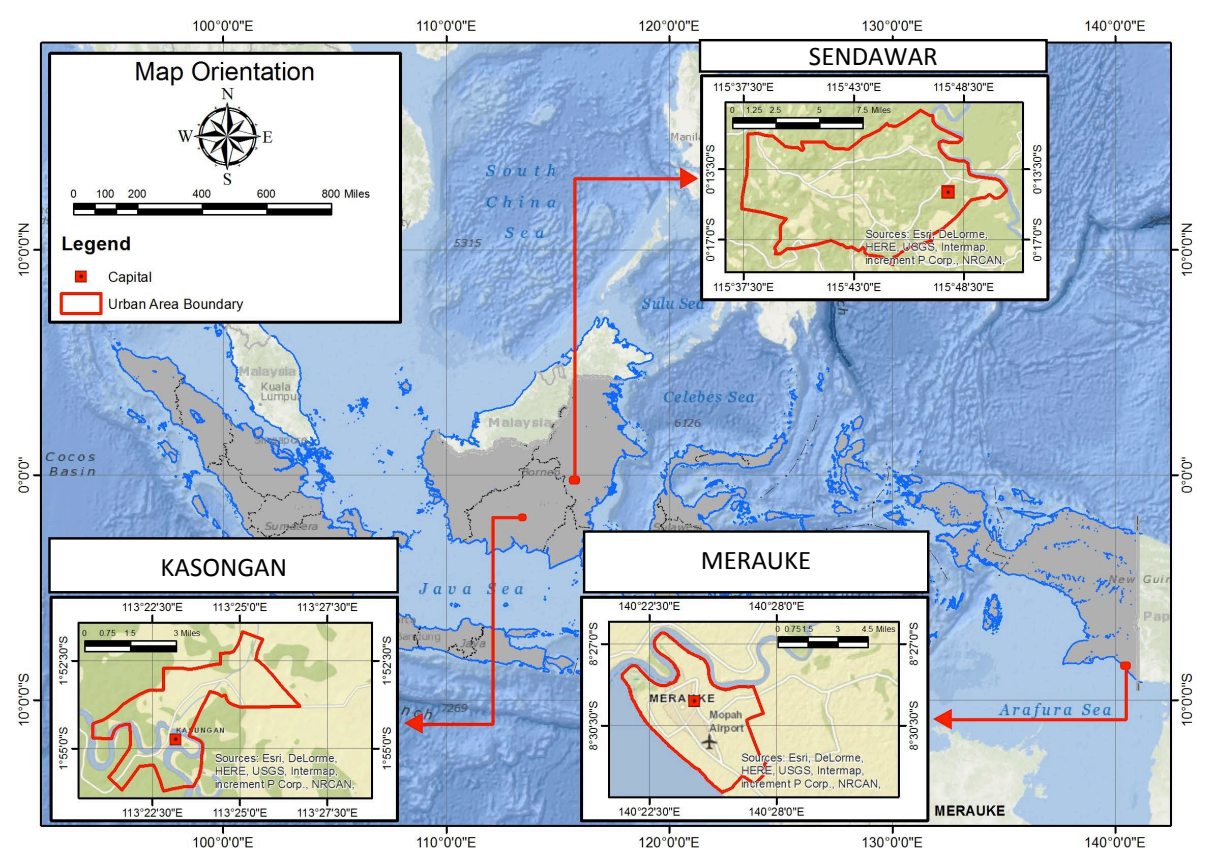

Figure 1. Orientation Map. Source: Authors, 2014 (Modified from Esri, Delome, USGS, Intermap, Increment P Corp., NRCAN).

\footnotetext{
${ }^{1}$ Approach derived from the proportion of the population of Kutai Barat district $(172,133)$ and Estimated Population living in urban areas Sendawar $(33,881)$ in $2010( \pm 19.68 \%$ of the population of Kutai Barat, live in urban areas at Sendawar). Kutai Barat Population is 184,394 inhabitants in 2012.
} 

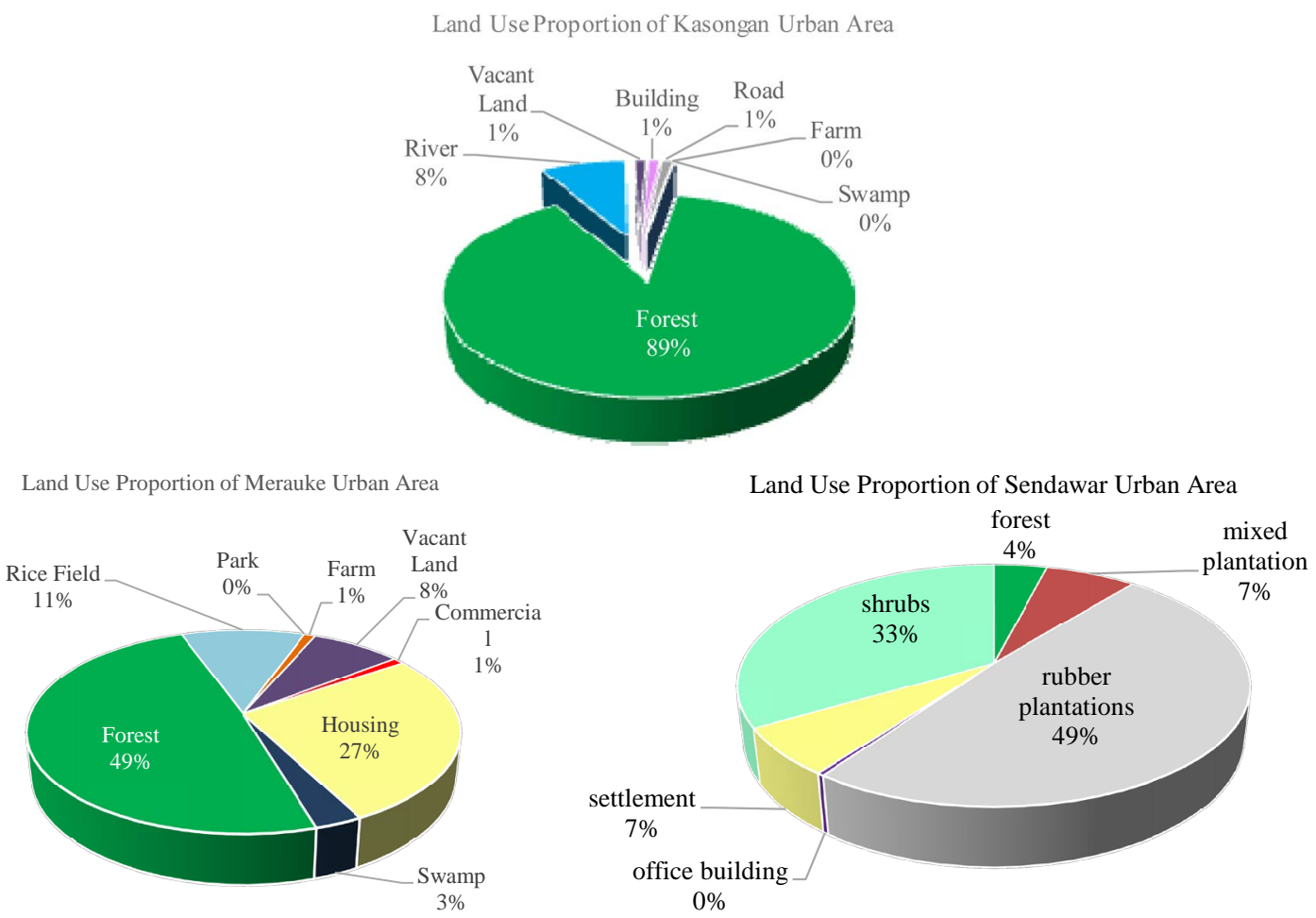

Figure 2. Land Use Proportion of Merauke (Bottom Left), Kasongan (Top Center), and Sendawar Urban Area (Bottom Right). Source: [17], [20]-[22].

citizens. There are only few developed by private developers or government agencies. The incompact settlement followed by limited basic infrastructures is the main those cities. The dominance of forest and swamps also indicates that there are still many potential development scenarios that may apply to those cities.

As assumed before that the small cities have stored carbon due to their land use pattern, we calculated the potential carbon sequestrations that they can obtain. Based on the assumptions of peat land use characteristics, we found that the existing condition of Kasongan contains more than 56 thousand ton carbons per year. Merauke would contain 89.3 thousand ton carbons per year and Sendawar would include more than 15.4 thousand ton per year (see Table 1 ).

Beside of the potential carbon storages, the small cities also assumed have low emission because of their small size urban activities. It assumed would only produce a small portion of carbon emission. However, since the technologies still relied on fuel fossil energy, it would still produce high carbon emission. Based on Intergovernmental Panel on Climate Change (IPCC) standard and on the assumption that the high emission comes from three major urban activities, energy, transportation, and industry, we could estimate the ratio between storage and emission that they possibly had. Table 2 showed that Kasongan (42.7 thousand ton) has lower emission rather than Merauke (109 thousand ton) and Sendawar (57.6 thousand ton).

If we compare Table 1 and Table 2, we found that only Kasongan has the storage level lower than emission level. The existing land use pattern makes Kasongan potentially as the carbon sinkers rather than emitter, but the high dependency on fossil fuel gas still can lead them to emit large numbers of carbon for the future. It would be a good start for Kasongan to develop neutral carbon development for the future. However, in the case of Merauke and Sendawar, the carbon potential of those cities indicates that the potential carbon sequestration has a significant amount in balancing the level emission, but still lower than the emission level. If assumed the tables are the baseline for low-carbon planning, then it would be two ways to make the development pathway. First, they need to maintain or even to extend the level of carbon storage and second, in the non-spatial aspect, the cities should provide more spaces and times to the low dense population and emerged modern activities using low-carbon technologies and green cultures. Therefore, we argue that the low carbon development pathway in the small cities does not have totally different baseline with metropolitan cities, which have already been developed. 
Table 1. Potential carbon sequestrations.

\begin{tabular}{|c|c|c|c|c|c|c|}
\hline City & Land Use & Area (ha) & $\begin{array}{c}\mathrm{CO}_{2} \text { Emission }_{\left(\text {ton }^{-1} a^{-1} \cdot \text { year }^{-1}\right)}\end{array}$ & $\begin{array}{l}\mathrm{CH}_{4} \text { Emission }^{-1} \\
\left(\text { ton }^{-1} \mathbf{a}^{-1} \cdot \text { year }^{-1}\right)\end{array}$ & $\begin{array}{c}\mathrm{CO}_{2} \text { Emission } \\
\text { Contained (ton/year) }\end{array}$ & $\begin{array}{c}\mathrm{CH}_{4} \text { Emission } \\
\text { Contained (ton/year) }\end{array}$ \\
\hline \multirow{2}{*}{ Kasongan } & Swamps & 7.07 & 38.90 & 0.014 & 275.10 & 0.10 \\
\hline & Forest & 2938.69 & 19.30 & 0.001 & 56716.66 & 2.94 \\
\hline \multicolumn{5}{|c|}{ Sum } & 56991.76 & 3.04 \\
\hline \multirow{3}{*}{ Merauke } & Swamps & 194.53 & 38.90 & 0.014 & 7567.22 & 2.72 \\
\hline & Forest & 3470.64 & 19.30 & 0.001 & 66983.35 & 3.47 \\
\hline & & 764.30 & 19.30 & 0.001 & 14750.99 & 0.76 \\
\hline \multicolumn{4}{|c|}{ Sum } & & 89301.56 & 6.96 \\
\hline Sendawar & Forest & 798.23 & 19,3 & 0.001 & 15405.83 & 0.80 \\
\hline \multicolumn{5}{|c|}{ Sum } & 15405.83 & 0.80 \\
\hline
\end{tabular}

Source: Authors, 2014. Based on land cover data in [17] [20]-[23].

Table 2. Potential Carbon Emission from urban sectors.

\begin{tabular}{|c|c|c|c|c|}
\hline \multirow{2}{*}{ Urban Sectors } & \multirow{2}{*}{ Estimated Numbers } & \multirow{2}{*}{$\begin{array}{c}\text { Standard Potential } \mathrm{CO}_{2} \text { Emission } \\
\left(\mathrm{t} \cdot \text { year }^{-1}\right)\end{array}$} & Total Potential $\mathrm{CO}_{2}$ Emission & \multirow{2}{*}{ Remark } \\
\hline & & & $\left(t \cdot y_{e a r}^{-1}\right)$ & \\
\hline \multicolumn{5}{|c|}{ Kasongan } \\
\hline Energy & 43,581,431 Kwh & $0.000454 \mathrm{Ton} / \mathrm{Kwh}$ & 19785.97 & Use diesel power plant \\
\hline Transport & 8,765,741 Liter & 0.002598 Ton/Liter & 22772.17 & Motorcycle + car + bus (fuel) \\
\hline \multirow[t]{2}{*}{ Industry } & 2 Hectare & 74.100000 Ton/Hectare & 148.20 & Small manufacture only \\
\hline & \multirow[t]{2}{*}{ Sum } & & 42706.34 & \\
\hline \multicolumn{4}{|c|}{ Merauke } & \\
\hline Energy & 22,161,050 Kwh & $0.000454 \mathrm{Ton} / \mathrm{Kwh}$ & 10061.12 & Use diesel power plant \\
\hline Transport & 38,243,174 Liter & 0.002598 Ton/Liter & 99350.41 & Motorcycle + car + bus \\
\hline \multirow[t]{2}{*}{ Industry } & 3 Hectare & 74.100000 Ton/Hectare & 222.30 & Small manufacture only \\
\hline & Sum & & 109633.83 & \\
\hline \multicolumn{5}{|c|}{ Sendawar } \\
\hline Energy & 32,491,341 Kwh & $0.000454 \mathrm{Ton} / \mathrm{Kwh}$ & 14751.07 & Use diesel power plant \\
\hline Transport & 16,468,819 Liter & $0.002598 \mathrm{Ton} / \mathrm{Liter}$ & 42783.69 & Motorcycle + car + bus \\
\hline Industry & 0.5 Hectare & 74.100000 Ton/Hectare & 37.05 & Small manufacture only \\
\hline \multicolumn{3}{|c|}{ Sum } & 57571.81 & \\
\hline
\end{tabular}

Source: Authors, based on own calculation, using modified method from the IPCC (2010). Note: Calculation of emissions from energy use assumptions electricity consumption approach; Because of limited data on transport sector, so the transport data presented here using the assumption of fuel per tank capacity of each type of vehicle (motorcycle + car + bus) and then multiplied by annual usage per day; The data from industrial sector using the assumption of vast proportions of land use existing from image satellite interpretation

\section{A Divergent Planned Pathway}

As argued above that the spatial planning can reduce the carbon emission, we would assess the planning policies regarding the future land use pattern, energy, transportation and urban form as stated in the spatial planning document of three respective cities. 
First, the land use plan chapter. There are three main analyses, first we analyzed the ratio of green open spaces to industrial and commercial zones since those zones are the most affecting activities to absorb and release carbon. Second, we calculated the proportion of built area and non-built area in order to know whether the planned land use pattern for up to 20 years has already shown low carbon development pathway or not. Third, we identified the potential carbon sequestration that they can get from their plan. Based on Figure 3, we found that first the ratio of green open space is still higher than industrial and commercial zone. Kasongan would have 30:1, Merauke 62:6, and Sendawar 35:9. Second, the proportion of built up is getting higher, but mostly for housing uses. Kasongan would have $57 \%$ built up area and Sendawar would have 65\%, except Merauke 38\%, which is lower than built up area. It thus indicates that the small cities have the adequate enough space for developing the low carbon pathway properly.

However, if we calculate the potential carbon sequestration based on the future land use pattern, we can see that only Merauke has the higher potential storage than the others (see Table 3).
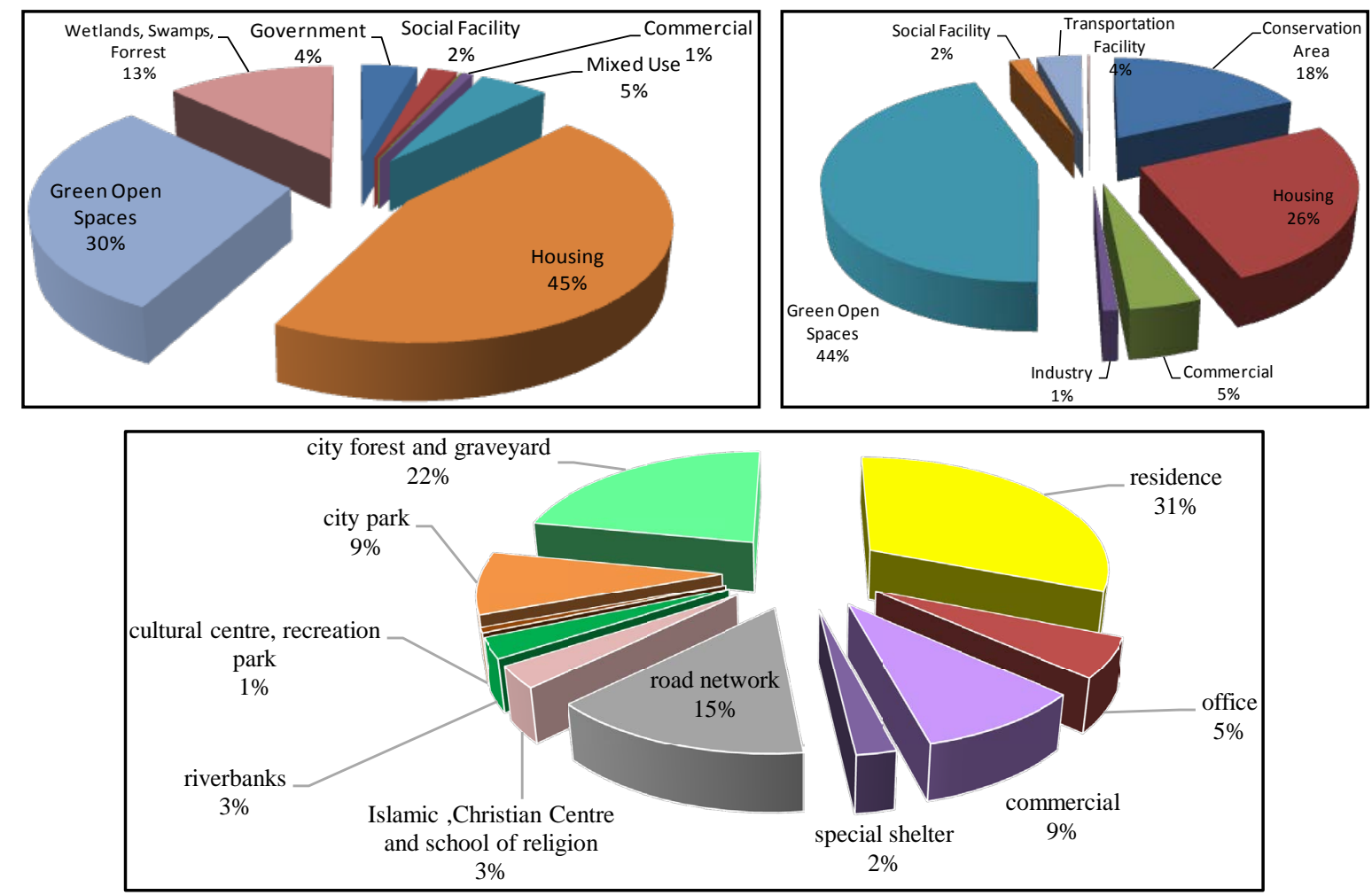

Figure 3. Planned land use pattern of Kasongan (left), Merauke (right), and Sendawar (center). Source: [17] [20] [22] [23].

Table 3. Potential carbon sequestration based on the spatial plan of three cities.

\begin{tabular}{|c|c|c|c|c|c|c|}
\hline & Land Use & Area (Hectare) & $\begin{array}{l}\mathrm{CO}_{2} \text { Emission } \\
\left(\mathrm{t} \cdot \mathrm{Ca}^{-1} \cdot \mathrm{year}^{-1}\right)\end{array}$ & $\begin{array}{l}\mathrm{CH}_{4} \text { Emission }^{-1} \\
\left(\mathrm{t} \cdot \mathrm{ha}^{-1} \cdot \text { year }^{-1}\right)\end{array}$ & $\begin{array}{c}\mathrm{CO}_{2} \text { Emission } \\
\text { Contained }\end{array}$ & $\begin{array}{c}\mathrm{CH}_{4} \text { Emission } \\
\text { Contained }\end{array}$ \\
\hline \multirow{3}{*}{ Merauke } & Conservation Area & 1.26655 & 40.00 & 0.013 & 50.66200 & 16.47 \\
\hline & Green Open Spaces & 3.11363 & 19.30 & 0.001 & 60.09306 & 3.11 \\
\hline & \multicolumn{3}{|c|}{ Sum } & & 110.75506 & 19.58 \\
\hline \multirow{3}{*}{ Kasongan } & Green Open Spaces & 812.46 & 19.30 & 0.001 & 15680.52 & 0.81 \\
\hline & Conservation Area & 459.51 & 40.00 & 0.013 & 18380.48 & 5.97 \\
\hline & \multicolumn{3}{|c|}{ Sum } & & 34061.00 & 6.79 \\
\hline \multirow{2}{*}{ Sendawar } & Green Open Spaces & 244.45 & 19.30 & 0.001 & 4.71789 & 0.24 \\
\hline & \multicolumn{3}{|c|}{ Sum } & & 4.71789 & 0.24 \\
\hline
\end{tabular}

Source: Authors, based on [17] [20] [22] [23]. 
Comparing to the previous storage that they had, the 20 years planned land use of Kasongan and Sendawar have decreasing function. In the contrary, Merauke has higher storage than the existing. It is estimated that Merauke would have 110 thousand ton carbon per year for the next 20 years, compare than the existing (89.3 thousand ton) (see Table 1 and Table 3). Therefore, the role of land use plan is very crucial in the beginning phase to set up the low carbon development pathway. However, things that need to be examined further is whether the low-carbon technology and culture will be implemented well in certain urban activities that have high potential emission, such as pesticide substances for farming land, fossil fuel-based infrastructure and transportation, and waste management in residential areas.

Second, the energy plan chapter. Merauke, Kasongan, and Sendawar are still depending on the diesel power to generate city electricity. There is no direction of energy policy to use the renewable energy. As stated in the spatial planning documents, for the next 20 years, the three cities still use diesel as the city's main power plant. Limitation of the technology and the absence of renewable energy sources were being the main reason. The potential of micro hydro and solar panel is not adopted because the local governments recognize that they are lack of sunray intensity and fast-flowing rivers (interviews with the government agencies, 2010, 2011, 2013). The recommendation for providing alternative sources of energy and environmental friendly technologies has faced the governmental budget limitation. Whereas the future supplies that needed is only 33.53 MWh for Merauke, 23.62 MWh for Sendawar and 27.17 h MW for Kasongan. Those energy policies showed the negative sign for low carbon development pathway.

Third, the transport plan chapter. Merauke and Kasongan still have low volume vehicle and a larger proportion of non-built spaces. The consultants and local governments have aggreed to provide more spaces for public transportation development. Both cities planned a Transit Oriented Development (TOD) system, with a terminal as the main node. Merauke has port and airport as other transport nodes. In addition, the spatial plan also directed the use of public transport through the provision of mass public transit lines that integrate with the main transport node. The plan also formed the pedestrian oriented city through provision of wide pedestrian way. Merauke even will have a road corridor in the town center, which is dedicated for pedestrians. The integrated transport plan above also shapes the urban form of Merauke and Kasongan to become more compact. It showed the positive signs and opportunities to develop an efficient, environmentally friendly, and low emission urban transportation system.

In Sendawar case, transport policy has not been directed toward the mass rapid transportation. The plan just still accommodated the existing trend condition in which most of the people choose to use private vehicles, especially motorcycles. The availability of public transportation is just only rental taxis, which are only used by people to travel across the city or district, not for inner city transportation. However, the problem was in community understanding in choosing transportation modes. Since the small size of the cities, the whole city can be reached easily by using a motorcycle. Nowadays, people in developing countries prefer to use motorcycle than on foot or public transportation. It would result in a low level of mass public transport service. It would also lead to high GHGs emissions from motorcycles. Cheap credit motorcycles ownership is one of the driving factors. It shows the high pressures from the motorcycle industry for the implementation of low carbon development.

Through these three case studies, we can interpret from the spatial planning documents that the planned pathway is still divergent to achieve a low carbon development. The future use of land use, energy, and transportation has no complementary or supplementary function to support each other performances. The land use plan did not explicitly consider the capture and storage of carbon in the planning documents. The energy plan did not mention yet about the plan to reduce the growth of fossil fuel use or to replace it by providing attractive policies for private investment. The transportation plan did not emphasize the integration of public transport and pedestrianization, except Merauke city. The integration among them should be planned properly to have better achievement on low carbon development.

\section{The Challenges in the Spatial Planning Process}

The future planning as described above was born from the participatory process, which involved many stakeholders. There are several lessons that can be generated from our involvement during the planning process as following:

Vision of the leader plays an important role. In general, the local government has had a long-term vision to develop green city and addressed it to the goal of spatial planning. We recognized from the statement of Bupati ${ }^{2}$

\footnotetext{
${ }^{2}$ Bupati is the head of district who managed the capital city of its district.
} 
Merauke for his vision to Merauke city. "Merauke should become the central hub of Indonesia in the eastern side. The infrastructure development should consider the efficiency of fuel consumption and mass-transit" (Interview with Bupati Merauke, 2011). It is congruent to the Bupati Katingan who also concerned about the riverside and peat land management in the Kasongan in order to achieve a sustainable city. Both Bupati also emphasized that the traditional value of the indigenous people there has acknowledged the green concepts.

Based on our interpretation, both visions of leaders are generated from their perception on the sustainable development, not particularly based on the green concepts since they did not clearly address the need of reducing GHGs emission. However, they have realized that green open space and energy efficiency are the important components for their urban development. They paid an enormous attention in the spatial planning processes because they fully understood about the usage of the spatial planning. Therefore, we argue that the leadership factor is very important in bringing the low carbon development vision to the spatial planning process. It confirms the argument that one of key success is senior leadership from within the government [5].

The role of non-state actors is crucial. City structure and land use plan was formulated through participatory process by involving consultant, local government, local community and NGOs. The multi-stakeholder involvement intends to formulate the potential aspects and problems more accurately and thoroughly. Based on the focus group discussion in three cities, we found that the community never said anything about any key concepts of low carbon development, such as green building, renewable energy, energy efficiency, or low carbon technologies. The local stakeholders only focused on instant problem solving that related to their livelihood and settlement, such as how to solve drainage channels that clogged with garbage, and floodwaters in the streets.

"They never said anything about green city. They only talk about instant solution for their environment problems, such as floods, garbage, water sanitation...” (Interview with the consultants, 2011).

In the other side, the local government had still an understanding that city development is only about developing economic infrastructures without concerning the carbon emissions. Nevertheless, it might still be balanced by the presence of international non-government organization (NGO), such as World Wide Fund (WWF)—in Meraukethat advocated and conveyed an understanding of the sustainable city development in the planning process. The competence of planning consultants is also helpful in addressing the low carbon agenda. As the member of Indonesian Association of Planners (IAP), most of the planning consultant has aware on the issues of climate change since one of the continuous professional development (CPD) of IAP covers the issue of climate change and spatial planning. Therefore, the idea of green city concept in the spatial planning process of Merauke, Kasongan, and Sendawar are transmitted from the planning consultant.

"We took the initiative to include green city concept into spatial planning. The idea did not come from the community. Bupati might be so, but peoples did not understand. The idea of a green city appeared mostly in our working studio, not in the public forum” (Interview with the consultant, 2011).

In the case of Sendawar, low carbon substance was just beginning to be integrated into the district spatial plan. WWF, through Land-Based Green Economy Program in Kutai Barat, offered the idea of low-carbon development. In the early stages, WWF in collaboration with the world agroforestry center (ICRAF) facilitated the development of the REL (Reference Emission Level) for the technical team of regional government of Kutai Barat ${ }^{3}$. Furthermore, through the LUWES (Land Use Planning for Low Emission Development Strategy) tool, WWF and ICRAFF assisted Government of Kutai Barat District to identify sources of emissions, calculate historical emissions, estimate future emissions into the historical account of emissions and the local development plan, determinate the Reference Emission Level (REL), and make the action plan as well as the strategy implementation in reducing emission [24]. Besides LUWES, multiple analysis tools used are Maxent and Zonation, which in this analysis the generated information is an indication of the spatial allocation plan that runs into the fastest rate of deforestation. Unfortunately, information about similar activities seems have not been carried out at the municipal level.

The institutionalization of low carbon notion at city level is needed. This study found that the driver of mainstreaming low carbon development into spatial planning process came from the idea of planning consultant. In Merauke and Kasongan, the local stakeholders, especially indigenous communities and government staffs did not own the conception of low carbon. Whilst, Moench as cited in Hedger et al. (2011) argued that "it is difficult to

\footnotetext{
${ }^{3}$ There are two approaches used and considered in the determination of the baseline or Reference Emission Level (REL), which is the baseline that is based on historical data (historical baseline) and baseline based on development plan that will come (forward-looking baseline). In these activities, development of low-emission or low-carbon development is defined as the development activities planned and implemented with the goal of improving welfare while reducing the impact of carbon emissions generated from the development activities.
} 
have systematic discussions on planning in the absence of well-grounded conceptual frameworks” [5]. Thus, the project catalyst 2009 has suggested that stakeholder engagement be one of the key success factors in making low carbon growth plan [25]. This study also showed that the small cities' stakeholders needed institutionalization process in order to socialize and internalize the low carbon knowledge in their everyday of life. The external actors, such as planning consultants and international NGOs, could play a significant role in the process since the local stakeholders were still lack of experiences.

The provision of scientific data and information is limited. In the case of Sendawar, based on the result of FGD, which also attended by APHI (Association of Indonesian Forest Concessionaires) noted that there is still lack of scientific data that can be used to identify the activities of carbon emission. The limitations of the data are especially related to large fires, land use permit (mining), the case of the expansion path passing in concessions, and splitting open village lands. Those make the model that has been made became less comprehensively ${ }^{4}$. We argue that the provision of supporting scientific data and information is also very important in bringing the low carbon development concept to be implemented. As stated by Hedger et al. (2011), to make low carbon growth successful, one of key success is a strong basis in scientific and economic data that yields a robust, credible assessment of mitigation potential and the costs of alternatives [5]. This issue is also likely to be met if the concept of low-carbon development will be implemented in the city-scale spatial planning.

The planning integration between district and city level is emerged. Sendawar case study also gives a lesson learnt regarding the importance of planning integration. As part of Kutai Barat regency, we start examining from district spatial plan (regional context) to Sendawar city plan. In the RTRW Kutai Barat (the bahasa acronym for the spatial plan of Kutai Barat district), it has been stated that the district should create harmonious and balancing function of the region. It should also intensify of the spatial use of cities and recover the carrying capacity of the environment to prevent the occurrence of a major disaster and ensure the sustainability development. The spatial plan of Sendawar has followed the RTRW Kutai Barat by allocating 34\% of its area to be green open space and recreation area. Therefore, the linkage of planning institution between macro and micro levels need to be established permanently to ensure the mainstreaming process run sustainably.

\section{Conclusions}

From our three different case studies, we found that the small cities do not directly have the advantages, as assumed before, to create development pathway easily through spatial planning. The institutional barriers have led them to the high emissions pathway, even though they have potential carbon storage. The different geographical location of small cities also contributes to the mainstreaming process. The coastal city that commonly develops faster than the city in the middle of and upstream area has easier process. The spatial plan of Merauke has demonstrated that the mainstreaming process has already been constituted in the spatial planning process. The land use plan of Merauke has the higher potential carbon sequestration for the next 20 years rather than the existing. The transportation system plan also has emphasized the public transport-oriented development, even though was not followed by the energy plan.

The mainstreaming of low carbon development into the spatial planning has actually occurred in the three respective cities. The role of non-state actors and leadership of the Bupati in the spatial planning process has a significant role in influencing the planning process. Nevertheless, the case study of Kasongan and Sendawar showed that the paradigm of low carbon development has only located in the realm of the leaders and mainstreamed at regional level. The planning institution has failed to derive the pathway into the spatial planning because the stakeholder engagement and technology adoption still remains weak. It indicates the absence of adaptive institutions to the shifting development paradigm. The shifted planning institution is needed to address new lowcarbon pathway. Therefore, we argue that the institutional barriers are constituted in mainstreaming the technical terms of low carbon development in the small cities.

Therefore, we suggest that providing technical support for creating low-carbon oriented spatial planning, strengthening the institutional capacity of local government agencies through the continuous education, and training program and empowering the local community through the community-based low carbon development should be conducted to optimize the mainstreaming process.

\footnotetext{
${ }^{4}$ Spoken by I Wayan Sujana as Komda APHI east Kalimantan province, in the Minutes of Meeting of Consolidated Reports of Land-Based Green Economy Programs on Kutai Barat, with DDPI, East Kalimantan Province, APHI and Management Unit, at Hotel Mesra, Samarinda, $4^{\text {th }}$ April 2013.
} 


\section{Acknowledgements}

The author thanks to the Universitas Indonesia and Australia Awards Jakarta for providing Workshop on Peerreviewed Journal Article Writing on September 2012.

\section{References}

[1] Wei, T. (2011) Building Low-Carbon Cities through Local Land Use Planning: Towards an Appropriate Urban Development Model for Sustainability. University of Nebraska, Lincoln, 7.

[2] UN Habitat (2011) Global Report on Human Settlements (GRHS): Cities and Climate Change. Earthscan, London.

[3] UNFCCC (2011) Outcome of the Work of the Ad Hoc Working Group on Long-Term Cooperative Action under the Convention Durban Climate Change Conference. Draft Decison [-/CP.17]. http://mitigationpartnership.net/sites/default/files/104.pdf

[4] van Tilburg, X., Würtenberger, L., de Coninck, H. and Bakker, S. (2011) Paving the Way for Low-Carbon Development Strategies. Energy Research Centre of the Netherlands (ECN). http://www.ecn.nl/docs/library/report/2011/e11059.pdf

[5] Hedger, M., Moench, M., Dixit, A., Kaur, N. and Anderson, S. (2011) Approaches to Planning for Climate Change: Bridging Concepts and Practice for Low Carbon Climate Resilient Development. Learning Hub, Brighton, 30, 32.

[6] Japan (2010) Low Carbon City Development Guideline: Outline. Ministry of Land, Infrastructure, Transport and Tourism of Japan. https://www.mlit.go.jp/common/000996971.pdf

[7] Clapp, C., Briner, G. and Karousakis, B. (2010) Low-Emission Development Strategies (LEDS): Technical, Institutional and Policy Lessons. OECD COM/ENV/EPOC/IEA/SLT.

http://www.oecd.org/environment/cc/climatechangeexpertgroupccxg.htm

[8] ICLEI (2013) Urban Low Carbon Development Strategy at Glance. ICLEI. http://urbanleds.iclei.org/index.php?id=108

[9] Widiantono, D.J. and Soepriadi, I. (2009) Menakar Kinerja Kota-Kota di Indonesia. Buletin Tata Ruang Kementerian Pekerjaan Umum Edisi Januari-Februari 2009, Jakarta. http://penataanruang.pu.go.id/bulletin/index.asp?mod=_fullart\&idart=120

[10] Indonesia (2011) Presidential Regulation No 61 Year 2011 of National Action Plan on GHGs Emissions Reduction, Government of Indonesia, Jakarta.

[11] Indonesia (2007) The Act No. 26 of 2007 Regarding the Spatial Management, Ministry of Public Work. Government of Indonesia, Jakarta.

[12] Indonesia (2011) The Green City Development Guide, Directorate General of Spatial Planning, Ministry of Public Work. Government of Indonesia, Jakarta.

[13] Indonesia (2013) Realizing the Smart City through Green City in Indonesia Center for Public Communication, Ministry of Public Works. Government of Indonesia, Jakarta. http://www.pu.go.id/m/main/view/9086

[14] Rieley, J.O., Wüst, R.A.J., Jauhiainen, J., Page, S.E., Wösten, H., Hooijer, A., Siegert, F., Limin, S.H., Vasander, H. and Stahlhut, M. (2008) Tropical Peatsland: Carbon Stores, Carbon Gas Emissions and Contribution to Climate Change Processes. Peatsland and Climate Change, 148-180. http://edepot.wur.nl/41970

[15] Merauke (2010) Merauke dalam Angka 2009. Badan Pusat Statistik Kabupaten, Government of Merauke District, Merauke.

[16] Katingan (2010) Katingan dalam Angka 2009. Badan Pusat Statistik Kabupaten, Government of Katingan District, Katingan.

[17] Kutai Barat (2005) Government Regulation of Kutai Barat District Number 37 Year 2005 Regarding Kutai Barat District Area. Government of Kutai Barat District, Kutai Barat.

[18] Kutai Barat (2010) Kutai Barat dalam Angka 2010. Badan Pusat Statistik Kabupaten, Government of Kutai Barat District, Kutai Barat.

[19] Swift, R.S. (2001) Sequestration of Carbon by Soil. Soil Science, 166, 858-871. http://dx.doi.org/10.1097/00010694-200111000-00010

[20] IPCC-Intergovernmental Panel on Climate Change (2010) Climate Design: Design and Planning or the Age of Climate Change. IPCC Forth Assessment Report, ORO Editions, Gordon Goff Publisher, Novato, California, United States.

[21] Merauke (2011) The Detail Spatial Plan of City of Merauke: Final Report. Dinas Tata Ruang, Government of Merauke District, Merauke.

[22] Katingan (2010) The Detail Spatial Plan of City of Kasongan: Final Report. Dinas Pekerjaan Umum, Government of 
Katingan District, Katingan.

[23] Kutai Barat (2013) The Spatial Planning of Kutai Barat 2010-2030: Final Report. Badan Perencanaan Pembangunan Daerah, Government of Kutai Barat District, Kutai Barat.

[24] WWF Indonesia (2013) Initial Draft of Document of Land Based Green Economy Programme, Kutai Barat and Mahakam Ulu. Unpublished Paper.

[25] Project Catalyst Brief (2009) Low Carbon Growth Plans: Advancing Good Practices. Working Draft 7 June 2009, Climate Works and European Climate Foundation, 5.

http://www.project-catalyst.info/images/3.\%20Low\%20carbon\%20growth\%20planning/Publications/Advancing\%20g ood\%20practice/091205\%20LCGP\%20Summary.pdf 
Scientific Research Publishing (SCIRP) is one of the largest Open Access journal publishers. It is currently publishing more than 200 open access, online, peer-reviewed journals covering a wide range of academic disciplines. SCIRP serves the worldwide academic communities and contributes to the progress and application of science with its publication.

Other selected journals from SCIRP are listed as below. Submit your manuscript to us via either submit@scirp.org or Online Submission Portal.
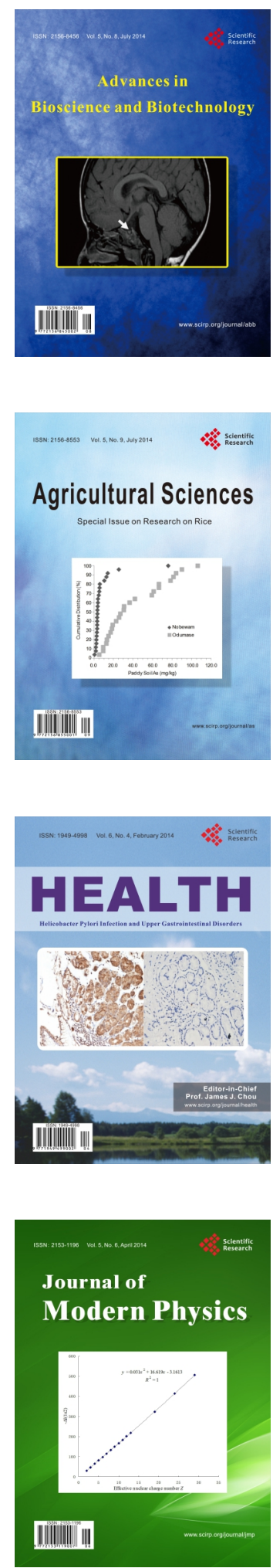
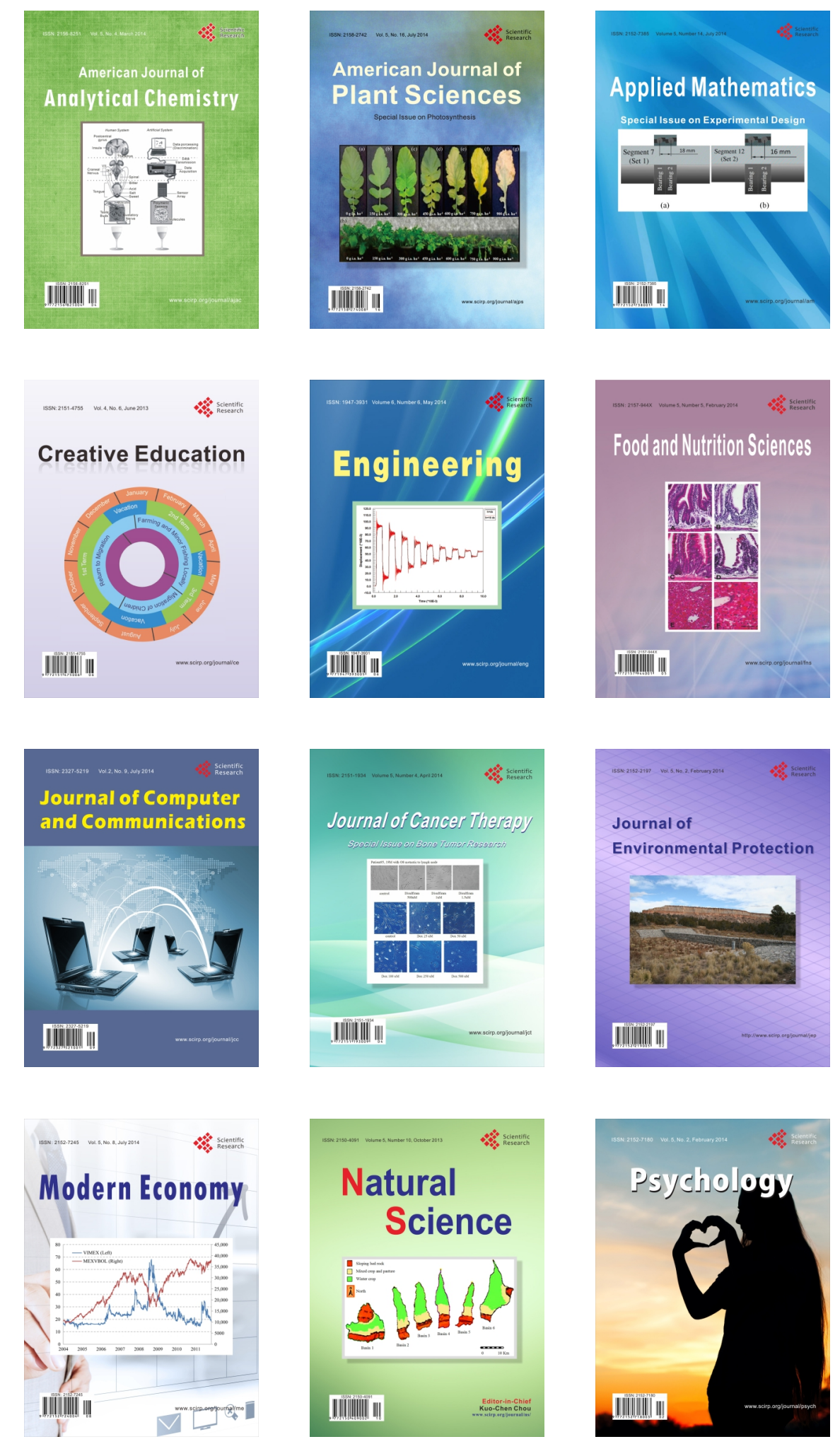